\title{
Moiré Patternのコントラストに関する考察と実験（その1）
}

\section{An experiment and a consideration about Moiré \\ Patterns contrast. (1)}

\section{by Mitsuyoshi Kureya.}

点屋充庸*

Studies and experiments to obtain contour lines of a non-topographic object have been conducted for some time, especially in the use of Moiré Pattern techniques by H. Takasaki and D. M. Meadows etc.

In these days, an evaluation of Moiré Pattern's photographs and a standardization of Moiré Pattern techniques must be considered. The author plans to study these problems and will be concerned with a contrast of Moiré fringes.

To analyze slit (or grid) geometry, a rectangular wave function is adopted for the transmission function. There are two reasons for adopting the rectangular wave function; namely, there exists a ratio between the width of the string and the space, and the distribution of light through a series of slits onto the object is observed as a rectangular wave. If only a sinusoidal function for a series of slits is used to express the transmission function, the effect of the ratio mentioned above can not be discussed in detail. The ratio $\mathrm{K}$ affects the brightness of the picture of Moiré Pattern and the noise introduced by these slits, or the grid.

In this paper, the ratio $K$ mentioned above is defined by [Gap's width]/[Black line's width], and if $K$ is contained within the transmission function, then the effect of the ratio $\mathrm{K}$ on the contrast can be discussed and some results shown.

\section{1.まえがき}

Non-Topographic な対象物の非接触三次元計測に関 する研究は, かなり古くから行われている。1960年代 においては, 丸安, 大嶋等による Stereo Photography の応用によるものが主であり, 筆者も 1963 年以降, Ortho-Contour Photography という題目で非接触三次元 計測に関する報告を行った。1970年代になると, 高崎 や, 或は D. M. MEDOWS 等によって Moiré Pattern に よる三次元計測の報告 ${ }^{1,2}$ が行われ, その後多くの分野 でモアレ縞に関する研究が盛んになった。Moiré 縞写 真の特徴は，物体表面の起状に関する多くの情報をそ の写真内にもっていることである。そこから等高線群 を抽出したり, 或は必要とする各種の計算処理を行う ことにより三次元計測の目的を果すことができる。こ の目的を果すためには，なるべく明瞭な Moiré fringeを 得ることが好ましい。すなわち，その後どのような手 段を用いてDataの処理を実行するにしても，よりよい

*群馬工業高等専門学校

「写真測量とリモートセンシング」vol. 17，№. 4， 1978
写真を得ることが必要である。

明瞭な縞模様を得ることにかかわる問題点について の報告，すなわち被写体表面における光の吸収とか， 反射に関する問題とか，格子条の材料或はレンズに関 する検討等に関する報告は高崎の報告 ${ }^{2}$ や B. DRERUP の報告 ${ }^{3)}$ を除いてはあまり見られない。，Moiré写真を使 用した三次元計測の精度を向上させるとか, 適用分野 に応じた標準化の問題を考えるときには，モアレ縞の コントラストに関する問題もそのなかにふくまれる。 すなわち，これらの問題についての実験例や経験を整 理する必要があると考え, 今回の考察と実験を行うこ とにした。

\section{Moiré 縞の明瞭度に影響を与えると考 えられる因子について}

写真フィルム上における等高線上の光の強度に関す る式 3-1-3 の係数の内容，すなわち

（1）被写体表面における光の反射

(2) 物体一レンズ間の距離（レンズの写界深度にも 関係してくる)

（3）被写体表面の起伏 
(4) 光 源

などが先ず挙げられる。また格子投影型にしても, 格 子照射型にしても実際には格子を構成する黒線と吵間 との間に一定の比（今後 Kで表わす）が存在する。こ の割合は当然，等高線上の光の強度と他の部分の明る さに関係すると考えられるので一つの因子となる。ま た格子条の材料とか, その表面の状態によっても写真 のできばえが変わってくる。そこでつぎの(5)と(6)を因 子のなかに加える。

（5）格子条の光の吸収・反射（String を使用した場 合，撚られているものか，然られたものでないかによ っても異なった結果が得られる)

(6) 間隙率 $\mathrm{K}$

モアレ縞のコントラストに実際に影響を与えるのは, 実効的な間隙率であるが，はじめは取扱いを簡単にす るため，格子自体のもつ間隙率によって考察する。

\section{3. 間乿率 Kについて}

上に列挙した因子のなかで，いままで論議されてい なかった格子条間隙率 $\mathrm{K} は ，$ 強度伝達関数を誘導する 場合に現われてくる值であるから理論式誘導の原点か ら記述する。また先にも触れたが，被写体表面の傾斜 (或は曲率) や, 位置の関係もいれてKの值と Moiré 縞 の強度の関係を誘導するのが一般的であると考えるが, 被写体の表面の状態は被写体自体に従属するものであ り，また格子条の形状に左右される実効的な $\mathrm{K}$ の值を とりいれることは問題を複雑にするので, ここでは格子 のもつ（格子条の隙間の配分から発生する割合）Kの 值が，強度伝達関数にどのように入りこんでくるかと 言う事から出発する。

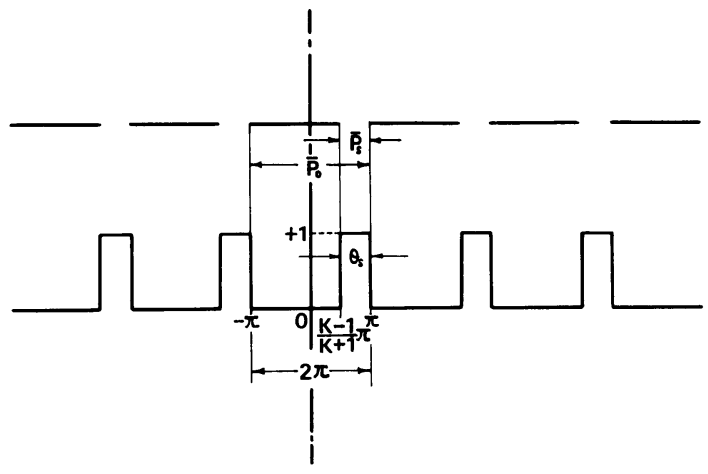

Fig. 1 The relation between Period and Light intensity
D. M. MEADOWS 等も光の強度伝達に矩形波を用い

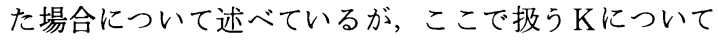
は言及していない。所謂光の強度と位相に関しては, 一 $\pi \sim 0$ に対して光の強度を $0,0 \sim \pi$ の範囲に対して 光の強度を 1 としたFourier Seriesによって扱っている。 また格子投影型の場合，光源側から被写体上に投ぜら れるスリット群像（或は格子像）の光の強度分布は矩 形波として扱うほうが現実的であり，殊にフィルム直 前にセットするスリット群は，矩形波として表わすの がよい。そこでFig. 1で示すようにスリットのピッチ $\bar{p}_{0}$ をつぎのよに $\mathrm{K} ： 1$ に内分して取り扱う。

(格子条の巾) : (隙間巾) $=\mathrm{K}: 1$

3.1 D. M. MEADOWS 等の Contour-term.

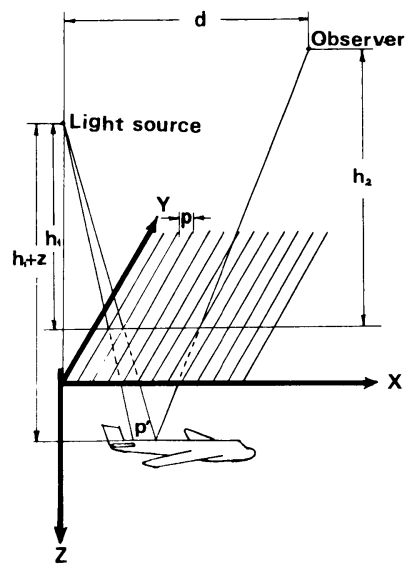

Fig. 2 Moiré contouring system by D.M. Meadows

Fig. 2において, 光源と観測者（或はカメラ）の格

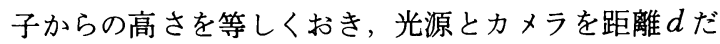
け離した場合について格子 Shadow の強度伝達をつぎ の式で与えている。

$$
T(x)=\frac{1}{2}+\frac{1}{2} g(2 \pi x / p)
$$

ここで, $g(2 \pi x / p)$ は任意の周期関数である。さら に

$$
C=\left(I_{0} / 4 r^{2}\right) \cos \phi(x, y, z) \cdots \cdots(3-1-2)
$$

とすれば，等高線化される物体表面の光の強度は

$$
\begin{aligned}
I(x, y)= & C\left\{1+g\left[\frac{2 \pi h x}{p(h+z)}\right]\right\} \\
& \left\{1+g\left[\frac{2 \pi(d \cdot z+h x)}{p(h+z)}\right]\right\}
\end{aligned}
$$


によって与えられ,ここでg $(2 \pi x / p)$ は Fourier Series

$$
g=\left(\frac{2 \pi x}{p}\right)=\sum_{n=1}^{\infty}\left(a_{n} \sin \frac{2 \pi n x}{p}+b_{n} \operatorname{Cos} \frac{2 \pi n x}{p}\right)
$$

$$
(3-1-4)
$$

である。これを式 $(3-1-3)$ にいれて整理し， $z$ のみ に左右される項によって与えられる

$$
\begin{aligned}
f(z)= & C\left[1+\sum_{n=1}^{\infty} \frac{1}{2}\left(a_{n}^{2}+b_{n}^{2}\right)\right. \\
& \left.\operatorname{Cos} \frac{2 \pi}{p}\left(\frac{n \cdot d \cdot z}{h+z}\right)\right] \quad \cdots \cdots(3-1-5)
\end{aligned}
$$

が, 等高線を表わすとい5ように式 $(3-1-5)$ を誘導 している。さらに，強度伝達関係が矩形波であるよう な格子を用いることが実験的には都合がよいとして矩 形波格子を

$$
T(x)=\frac{1}{2}+\frac{2}{\pi} \sum_{\substack{n=1 \\ n=0 d d}}^{\infty} \frac{1}{n} \operatorname{Sin} \frac{2 \pi n x}{p}
$$

によって与え, その場合の $f(z)$ をつぎのように示し ている。

$$
f(z)=C\left[1+\frac{2}{\pi^{2}} \sum_{\substack{n=1 \\ n=0}}^{\infty} \frac{1}{n^{2}} \operatorname{Cos} \frac{2 \pi}{p}\left(\frac{n \cdot d \cdot z}{h+z}\right)\right]
$$

\section{2 間隙率Kをいれた場合}

本報告の趣旨を明確にするために， 3.2 で D. M. MEADOWS等による式の誘導に触れたが，一般に周期 を $2 \pi$ とすれば, Fourier Series は

$$
f(\varphi+2 \pi)=f(\varphi)
$$

であり, $f(\varphi)$ に関する積分が存在するとすれば $f(\varphi)$ は

$$
f(\varphi) \approx \frac{a_{0}}{2}+\sum_{n=1}^{\infty}\left(a_{n} \operatorname{Cos} n \varphi+b_{n} \operatorname{Sin} n \varphi\right)
$$

によって表わされる。ここには

$a_{n}=\frac{1}{\pi} \int_{-\pi}^{\pi} f(\varphi) \operatorname{Cos} n \varphi \cdot d \varphi(n=0,1,2, \cdots)$

$b_{n}=\frac{1}{\pi} \int_{-\pi}^{\pi} f(\varphi) \operatorname{Sin} n \varphi \cdot d \varphi$

なる関係がある。

ここで，先に触れたごとく

（格子条巾）：(隙間巾） $=\mathrm{K}: 1=\left(2 \pi-\theta_{s}\right): \theta_{s}$

$$
=\left(\overline{p_{o}}-\overline{p_{s}}\right): \overline{p_{s}}
$$

とおけば（参照Fig.1）

$$
\theta=\frac{K-1}{K+1} \pi
$$

といら関係があり，スリットを通過した光の強度分布 を

$$
T(\varphi)=\left\{\begin{array}{l}
0 \quad\left(-\pi \leqq \varphi<\frac{K-1}{K+1} \pi, \varphi=\pi\right) \\
+1\left(\begin{array}{l}
K-1 \\
K+1
\end{array} \pi \leqq \varphi<\pi\right)
\end{array}\right.
$$

のように定めれば, $a_{n} や b_{n}$ は

$$
a_{o}=\frac{1}{\pi} \int_{-\pi}^{\frac{K-1}{K+1} \pi} O \cdot d \varphi+\frac{1}{\pi} \int_{\frac{K-1}{K+1} \pi}^{\pi} 1 \cdot d \varphi=\frac{2}{K+1}
$$

$$
a_{n}=\frac{1}{\pi} \frac{\int_{K-1}^{\pi} \pi}{K+1} \operatorname{Cos} n \varphi \cdot d \varphi=\frac{-1}{n \pi} \operatorname{Sin} \frac{n(K-1)}{K+1} \pi
$$

$$
\begin{aligned}
b_{n}= & \frac{1}{\pi} \int_{\frac{K-1}{K+1} \pi}^{\pi} \operatorname{Sin} n \varphi \cdot d \varphi=\frac{1}{n \pi}\left[\operatorname{Cos} \frac{n(K-1)}{K+1} \pi\right. \\
& -\operatorname{Cos} n \pi] \quad \cdots \cdots \cdots \cdots \cdots \cdots \cdots \cdots \cdots \cdots \cdots(3-2-6)
\end{aligned}
$$

のように与えられ

$$
\begin{aligned}
T(\varphi) & =\frac{a_{o}}{2}+\sum_{n=1}^{\infty} a_{n} \operatorname{Cos} n \varphi+\sum_{n=1}^{\infty} b_{n} \operatorname{Sin} n \varphi \\
& =\frac{1}{K+1}+\sum_{n=1}^{\infty} \frac{(-1)}{n \pi} \operatorname{Sin} \frac{n(K-1) \pi}{K+1} \operatorname{Cos} n \varphi \\
& +\sum_{n=1}^{\infty} \frac{1}{n \pi}\left[\operatorname{Cos} \frac{n(K-1) \pi}{K+1}-\operatorname{Cos} n \pi\right] \\
& \operatorname{Sin} n \varphi
\end{aligned}
$$

を得る。この式において $K=1$ とすれば先に引用した 式 (3-1-6) と全く同一のものを得る。そこで矩形波 関数として式 (3-2-7) を用い，物体表面上に投影さ れた格子条の像 $Q\left(x, y, z_{1}\right)$ の位相を $\varphi_{1},(F i g .3$ 参照), カメラ側の格子に対応する $Q$ 点の位相を $\varphi_{2}$ とす れば, $Q\left(x, y, z_{1}\right)$ 点を含む等高線の存在する物体 表面の光の強度は

$$
\begin{aligned}
I(x, y)= & C^{\prime}\left[\frac{1}{K+1}+\sum_{n=1}^{\infty} a_{n} \cos n \varphi_{1}+\sum_{n=1}^{\infty} b_{n}\right. \\
& \left.\operatorname{Sin} n \varphi_{1}\right]\left[\frac{1}{K+1}+\sum_{n=1}^{\infty} a_{n} \cos n \varphi_{2}+\right. \\
& \left.\sum_{n=1}^{\infty} b_{n} \sin n \varphi_{2}\right] \quad \cdots \cdots \cdots(3-2-8)
\end{aligned}
$$

ここで $C^{\prime}$ は $C^{\prime}=\left(I_{o} / r^{2}\right) \cos \phi(x, y, z)$ である。 さらに展開してつぎの式を得る。 


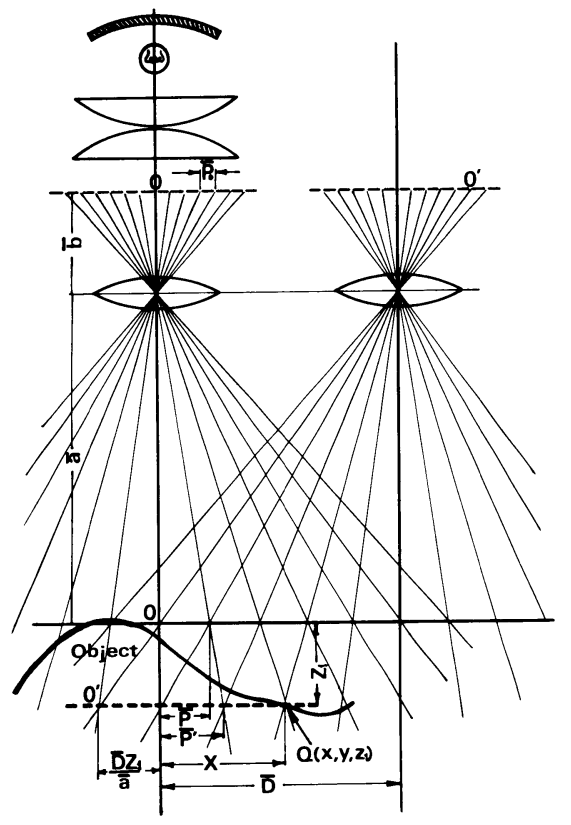

Fig. 3 Schematic diagram of the projection type Moiré topography

$$
\begin{aligned}
I(x, y)= & C^{\prime}\left[\frac{1}{(K+1)^{2}}+\frac{1}{(K+1)}\left\{\sum \left(a_{n} \cos n \varphi_{1}\right.\right.\right. \\
+ & \left.b_{n} \sin n \varphi_{1}\right)+\sum\left(a_{n} \cos n \varphi_{2}+b_{n} \operatorname{Sin}\right. \\
& \left.\left.n \varphi_{2}\right)\right\}+\sum\left\{\frac{a_{n}^{2}-b_{n}^{2}}{2} \cos n\left(\varphi_{1}+\varphi_{2}\right)\right. \\
& \left.+a_{n} b_{n} \operatorname{Sin} n\left(\varphi_{1}+\varphi_{2}\right)\right\}+\sum_{p \neq q} \\
& \left\{\frac{a_{p} a_{q}-b_{p} b_{q}}{2} \cos \left(p \varphi_{1}+q \varphi_{2}\right)\right. \\
& +a_{p} b_{q} \operatorname{Sin}\left(p \varphi_{1}+q \varphi_{2}\right)+\frac{a_{p} a_{q}+b_{p} b_{q}}{2} \\
& \left.\operatorname{Cos}\left(p \varphi_{1}-q \varphi_{2}\right)\right\} \\
+ & \left.\sum \frac{a_{n}^{2}+b_{n}^{2}}{2} \operatorname{Cos} n\left(\varphi_{1}-\varphi_{2}\right)\right]
\end{aligned}
$$

ここで Fig. 3を参照すれば

$$
\left.\begin{array}{l}
\varphi_{1}=\frac{2 \pi}{\bar{p}} \frac{\bar{a} x}{\bar{a}+z_{1}} \\
\varphi_{2}=\frac{2 \pi}{\bar{p}^{\prime}}\left(\frac{\bar{D} \cdot z_{1}}{\bar{a}}+x\right)=\frac{2 \pi}{\bar{p}}\left(\frac{\bar{D} \cdot z_{1}}{\bar{a}+z_{1}}+\frac{\bar{a} x}{\bar{a}+z_{1}}\right)
\end{array}\right\}
$$

なる関係があることは明らかであるから

$$
\operatorname{Cos} n\left(\varphi_{1}-\varphi_{2}\right)=\operatorname{Cos} \frac{2 \pi}{\bar{p}} \frac{n \cdot \bar{D} \cdot z_{1}}{\bar{a}+z_{1}}
$$

を得る。したがってKをとりいれた場合の $f(z)$ は

$$
\begin{aligned}
& f(z)=C^{\prime}\left[\frac{1}{(K+1)^{2}}+\sum_{n=1}^{\infty} \frac{a_{n}^{2}+b_{n}^{2}}{2} \cos \frac{2 \pi}{\bar{p}}\right. \\
& \left.\frac{n \cdot \bar{D} \cdot z}{\bar{a}+z}\right]
\end{aligned}
$$

となる。また等高線として現われる $z$ 座標については,

$$
\frac{2 \pi \bar{D} z_{N}}{\bar{p}\left(\bar{a}+z_{N}\right)}=2 \pi N
$$

なる関係から， $z$ を求めることが知られている。 $N$ は $0,1,2, \cdots \cdots$ 小る整数であってモアレ縞の次数を示す。 すなわち Contour-term を構成している

$$
\operatorname{Cos} \frac{2 \pi}{\bar{p}} \frac{n \cdot \bar{D} \cdot z}{\bar{a}+z}
$$

の各項が最大値 1 となることから引き出されたのであ るが，各項の振巾は $\left(a_{n}^{2}+b_{n}^{2}\right) / 2$ によって与えられる ので等高線上の光の強度は $\left\{1 /(K+1)^{2}+\sum\left(a_{n}^{2}+\right.\right.$ $\left.\left.b_{n}^{2}\right) / 2\right\}$ に比例する。ただし， $C^{\prime}$ はいまほぼ一定と考 えている。しかし，コントラストについて考えると， $1 /(K+1)^{2}$ の項や，ノイズ項についても綜合的に扱っ て等高線項と対照させたい。そこで，はじめに(1)格子 自体の $\mathrm{K}$ が等高線項にどのように入りこんでくるか。 また $\mathrm{K} の$ 異なる格子を使用したモアレ写真相互の比較 によって全体の傾向をつかむ。(2)実効的な K の影響に ついて考察する。(3)実験的に

$$
\frac{I_{\max }-I_{\min }}{I_{\max }+I_{\min }}
$$

を求め, $K$ との関倸を調べる。ここで $I_{\max }$ や $I_{\text {mix }}$ は，被写体面上のある領域内における明るさの最大值，

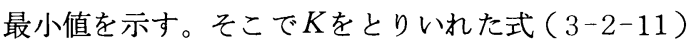
を手がかりとして，間隙率 $K$ とコントラスとに関する 考察と実験を，上記の(1)，(2)，(3)の順序に従って進め る。

\section{4. 方法, 実験装置及び結果}

$4.1 \sum\left(a_{n}^{2}+b_{n}^{2}\right) / 2$ の収東値と $f(z)$ の値につい $\tau$

式（3-2-11）の倸数 $C^{\prime}$ をほぼ一定とみてよい領域

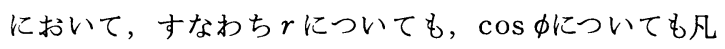
そ一定とみなせる被写体上の領域内で，モアレ縞のコ ントラストと $K$ 值がどんな関係になっているかを考 察するためには， $n$ をある程度大きくしていき

$$
\sum_{n=1}^{\infty} \frac{a_{n}^{2}+b_{n}^{2}}{2}
$$


が，どのような収束值を示すかを調べなければならな い。そこで式 (3-2-5) と式 (3-2-6) から

$$
\begin{gathered}
\sum_{n=1}^{\infty} \frac{a_{n}^{2}+b_{n}^{2}}{2} \fallingdotseq \sum_{n=1}^{n} \frac{1}{n^{2} \pi^{2}}\left[1-(-1)^{n} \cos \right. \\
\left.\frac{n(K-1)}{K+1} \pi\right] \quad \ldots \ldots \ldots \ldots \ldots \ldots \ldots \ldots \ldots \ldots
\end{gathered}
$$

を求めて，Kを $0.3,0.5,1.0,2.0,3.0$ と変え，そ れぞれに対する $\Sigma\left(a_{n}^{2}+b_{n}^{2}\right) / 2$ の值が $n$ を増大した場 合にどのように変化するかを確かめる。その計算值を Table.1に示す。出発点において強度伝達関数を 0 〜 1 の間の值をとる矩形波としたのであるから，等高 線上の強度の絶対值はノイズ項を除いて考えれば,

\begin{tabular}{|c|c|c|c|c|c|c|c|c|c|}
\hline K N & 162 & 188 & 2160 & 2460 & 2780 & 3120 & 3480 & 3860 & 4260 \\
\hline 0.3333 & 0.1869 & 0.1870 & 0.1874 & 0.1874 & 0.1874 & 0.1874 & 0.1874 & 0.1874 & 0.1874 \\
\hline 0.5000 & 0.2216 & 0.2217 & 0.2221 & 0.2221 & 0.2221 & 0.2221 & 0.2221 & 0.2221 & 0.2221 \\
\hline 1.0000 & 0.2494 & 0.2495 & 0.2499 & 0.2499 & 0.2499 & 0.2499 & 0.2499 & 0.2499 & 0.2499 \\
\hline 2.0000 & 0.2216 & 0.2217 & 0.2221 & 0.2221 & 0.2221 & 0.2221 & 0.2221 & 0.2221 & 0.2221 \\
\hline 3.0000 & 0.1869 & 0.1870 & 0.1874 & 0.1874 & 0.1874 & 0.1874 & 0.1874 & 0.1874 & 0.1874 \\
\hline
\end{tabular}

Table. 1

$1 /(K+1)^{2}$ の值をベースとして成りたっている。し たがって, その值を加えて式 (3-2-11) のC'に乗ぜ らるべき〔]内の值を示すと
$K の$ 值
3.0
2.01 .0
0.50
0.33
[ ] の值
0.25
0.33
0.50
0.66
0.78

のようになる。しかし, 実際にはノイズ項も存在する ので, コントラストとしての評価は式 (3-2-13) で示 されるような物理的意味をもつ方法によって評価され るべきである。式 $(3-2-13)$ による評価は実験的に 行ない。その結果は今後の報告の中で示す。

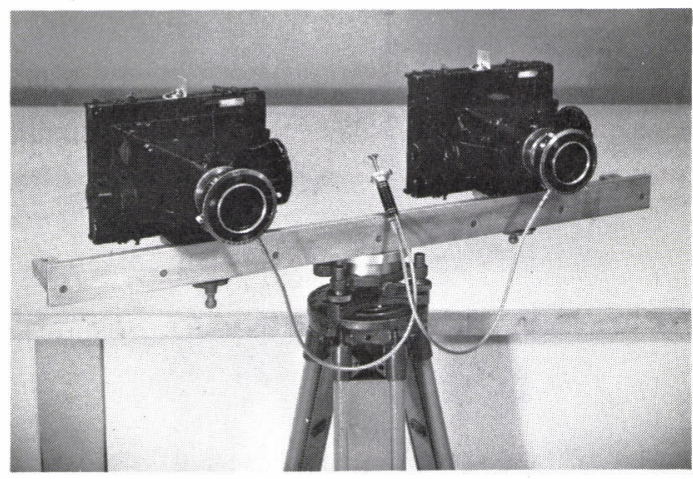

Fig. 4 Stereo-camera used for the projection type

\section{2 格子投影型についての実験}

Fig. 4 に示されている一組の立体写真用力メラを 用いた。すなわち一台のカメラを光源部とし, 他の一 台のカメラを撮影力メラとした。この立体写真用カメ ラのレンズは, ZEISS TESSAR, 焦点距離 $f$ は $150 \mathrm{~mm}$, F 6・3 である。また Letraset 不硬調フィルムに焼きつ
けて格子を作成した。使用したレトラセットは，25・50 lines / cm の 10, 20, 30,40,50\%と 16・75 lines / $\mathrm{cm}$ の $10,20 ， 30 ， 40 ， 50 \%$ とい5ぞれぞれ 5 種の 2 系 列, 計 10 種である。ここに使用されている\%の值はピ ッチに対する黒線巾の割合を百分率で示したものであ るが，これらを使用して作成した格子は白黒反転して いる。その上作成したものを工場顕微鏡等で実測しな ければ実際の割合を示すことにならないので, 実測し た Kの值を各系列について示すとつぎのようになる。

25・50 lines / cmの系列から作成したものは, ピッ チ : $0.40 \mathrm{~mm}, K$ の值 : $1 \cdot 3(50 \%), 1 \cdot 8(40 \%)$, $2 \cdot 1(30 \%), 3 \cdot 6(20 \%), 7 \cdot 5(10 \%)$

16・75 lines / cmの系列から作成したものは, ピッ チ：0・61 mm, Kの值: $1 \cdot 2(50 \%), 1 \cdot 5(40 \%)$, $2 \cdot 3(30 \%), 4 \cdot 3(20 \%), 12 \cdot 6(10 \%)$

ここで（）内の值は，レトラセットに表示されて いる百分率。

このようにして作成した格子を Fig. 3のように通常 フイルムまたは写真乾板をセットする場所に配置して 格子投影型を構成する。すなわち同じ $K$ の值をもつ一 組の格子によって対象とするモデルの写真を撮影し, 順次異なった $K$ の值をもつ一組の格子にかえて同一対 象物体の写真を撮影し，それらを互に比較する。した がって, すべての撮影について, 同一露出（露出時間： 15秒) でシャッターをきり, 同一条件の下で各乾板を 現像する。(現像温度 : $20^{\circ} \mathrm{C}$, 現像時間： 5 分, 定着 時間：20分)。またそれらの陽画を同一条件の下で作 成する。具体的に示すと, Fig. 5 のシリースについて は, プリント時間： $2 \cdot 4$ 秒, 現像温度 : $20^{\circ} \mathrm{C}$, 現像時 


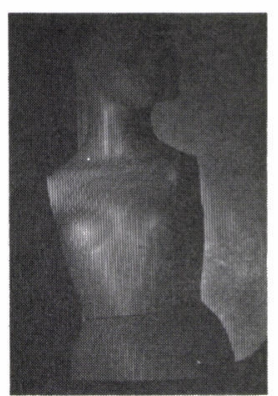

(a) 7.5

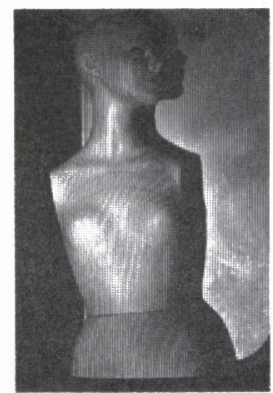

(b) 3.6

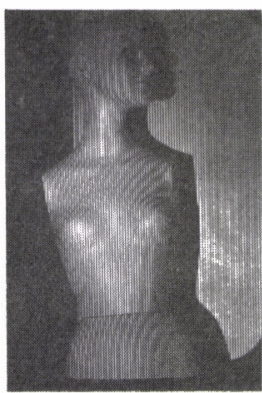

(c) 2.1

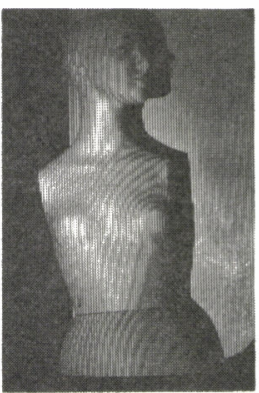

(d) 1.8

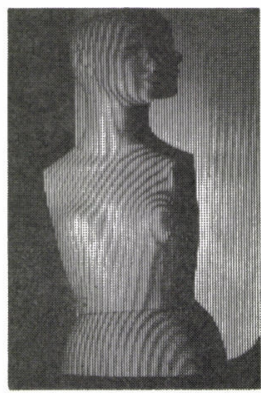

(e) 1.3

Fig. 5 Pitch $0.40 \mathrm{~mm} 2.4 \mathrm{sec}$ for the print

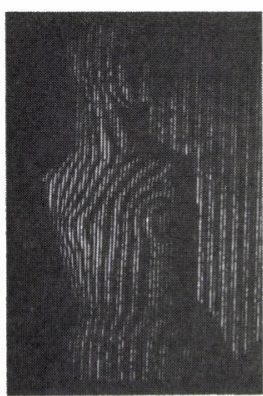

(a) 12.6

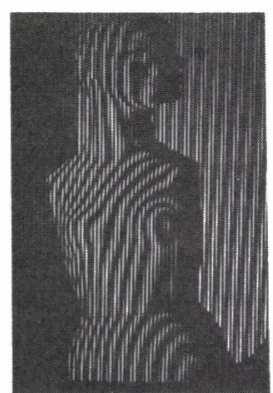

(b) 4.3

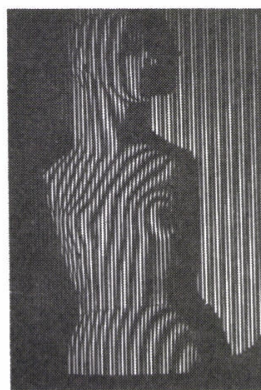

(c) 2.3

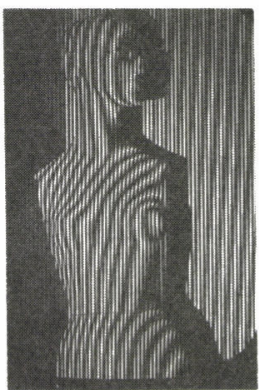

(d) 1.5

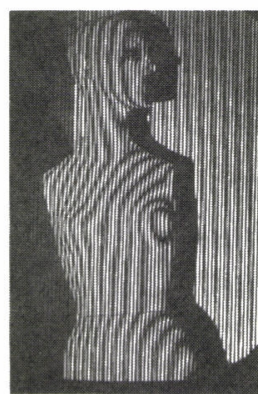

(e) 1.2

Fig. 6 Pitch $0.61 \mathrm{~mm} 1.4 \mathrm{sec}$ for the print

間：90秒，定着時間：15 分である。Fig. 6 のシリー スについては，プリント時間 $1 ・ 4$ 秒で，現像温度，現 像時間，定着時間はFig.5のシリースのものと全く同 一である。このようにして得た各写真の下に $K$ の値を 付しそれらをFig. 5, Fig. 6 亿揭載した。また両シリー スとも, 被写体とカメラの距離は $2 \cdot 2 \mathrm{~m}$ である。

\section{3 格子照射型についての実験}

格子照射型の場合も, 間隙率（ここでも間隙率は格子 条の配列できまる格子自体の $K$ ことで, 格子条の形 状による実効的な値や, 被写体の位置や, 被写体面の 勾配等による変化は考えていない）は格子投影型の場 合と全く同様に考えられるので, Fig. 7 亿示す装置 (NRCのM. C. VAN WIJK や, M. PAULUN 等に よって開発された）に，異なった間隙率 $K$ をもつ格子 を配して実験を行った。Fig. 8は格子の配置を示寸説 明図である。今回の実験には, 黒の撚り系 (ナイロン, 直径 $0.6 \mathrm{~mm}$ ) 用いて $\mathrm{A}, \mathrm{B}, \mathrm{C}, \mathrm{D}, \mathrm{E}$ の 5 種の格子 を作成した。この場合, 系の直径はみな $0.6 \mathrm{~mm}$, した がって異なった間隙率をもたせるためにそのピッチを 変えて格子を作成した。つぎに $K$ の値と, それに対 応するピッチの值を列挙する。撮影には, レンズ：

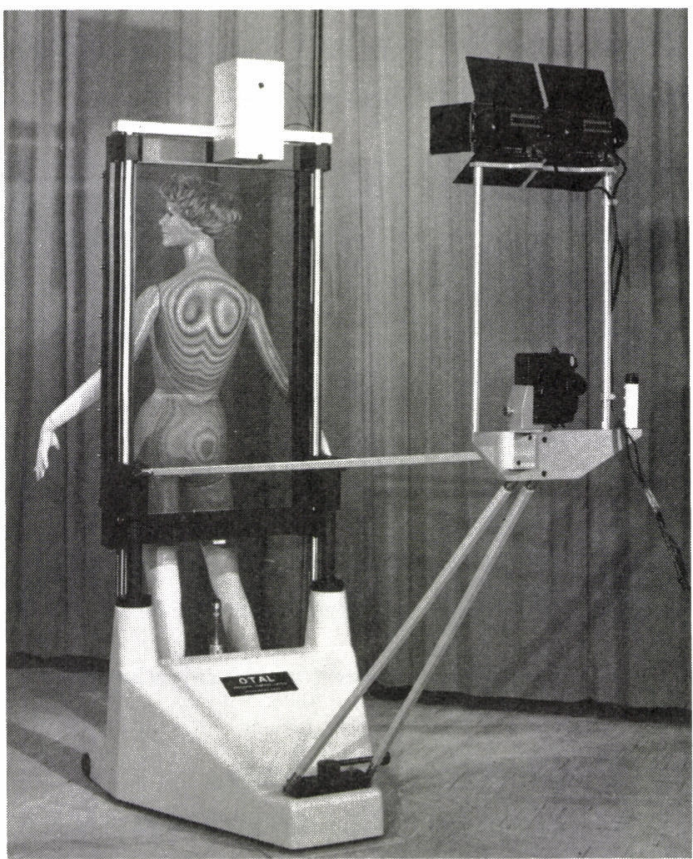

Fig. 7 Apparatus of Moirétopography 


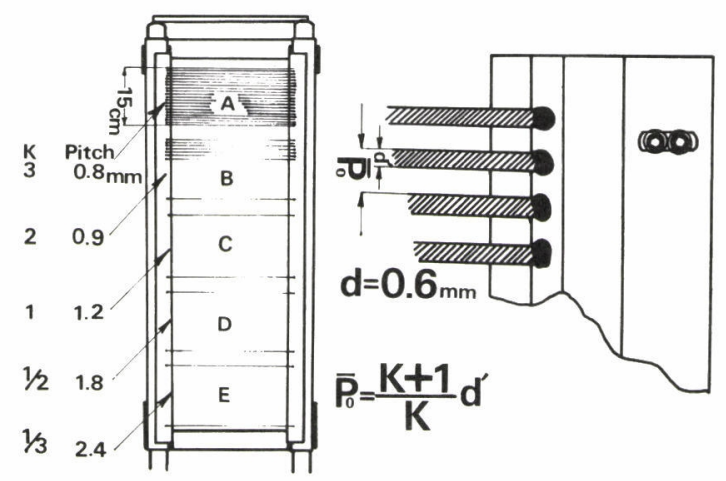

Fig. 8 Structure of the grid

\begin{tabular}{c|ccccc} 
格子名 & $\mathrm{A}$ & $\mathrm{B}$ & $\mathrm{C}$ & $\mathrm{D}$ & $\mathrm{E}$ \\
\hline Kの值 & 3 & 2 & 1 & 0.5 & 0.3 \\
\hline ピッチ & $0.8 \mathrm{~mm}$ & 0.9 & 1.2 & 1.8 & 2.4
\end{tabular}

NIKKOR 50mm, F1：2を用い, フィルムとしては, TRIX (ASA 400 ) を用いた。光源部の照明ランプは QUARTZ STUDIO LITE:LAMP TYPE QSL, 1,000 watts, 27,000 lumens, KELVIN 3,200 ${ }^{\circ}$, LAMP LIFE 75 HRS である。

Fig. 9はマネキンの全体像を撮影したもので, Fig. 10 は格子 Aと B による写真である。これらの写真のフ イルム現像時間は 3 分, 現像温度 $20^{\circ} \mathrm{C}$, 定着時間 15 分。

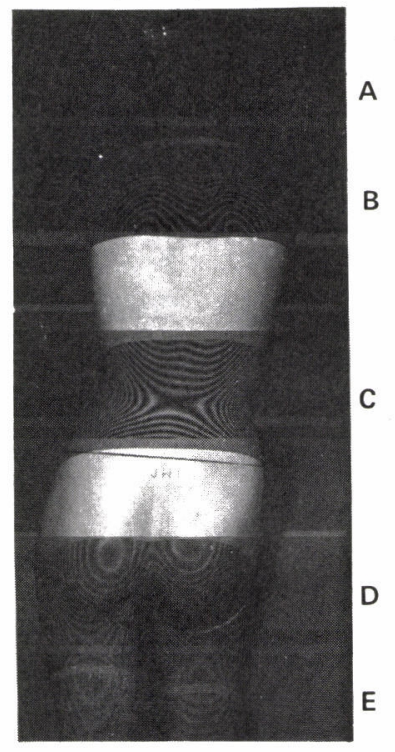

Fig. 9 F $8,1 / 60$ sec

\section{5. 結果についての考察}

目的とした間隙率とコントラストの関係について綜

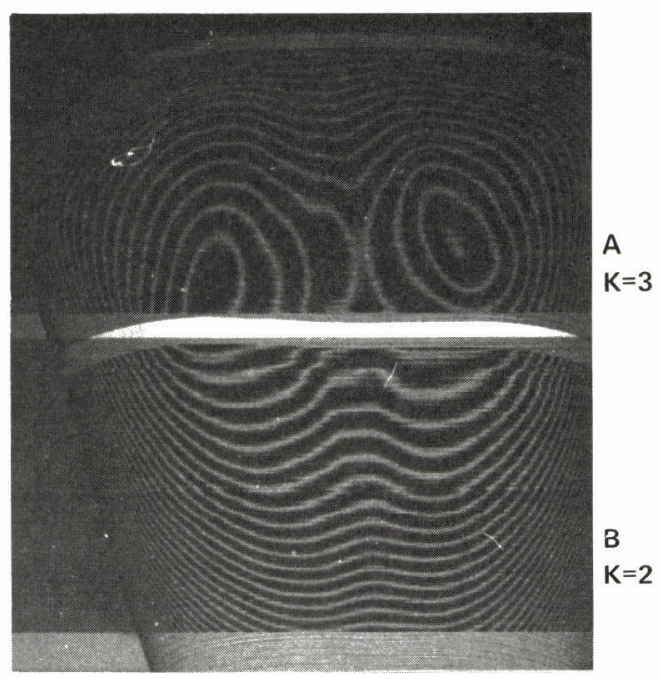

Fig. 10 F 5.6, 1/30sec

合的な結論を下すことはまだできないが，今回なし得 たことを挙げるとつぎのようになる。

(a) 格子条の配列から発生する格子自体の $K$ を強度 伝達関数のなかにとりいれることができ，Kの值が変 わると等高線上の強度が $\mathrm{K} の$ 変化に応じて変わるとい ら理論的根拠を示すことができた。

(b) Fig. 5, Fig. 6の写真から, モアレ縞写真のコ ントラストは格子自体の間隙率にかなり影響されてい るといら事を実験的に示すことができた。

ここでモアレ縞撮影装置等に関する標準化と言う問 題について触れる。近年医学の分野に扮ける応用例, すなわち側彎症の一次診断にモアレ縞写真を適用して いる研究者の発言の一部に「Pattern 分類や, 計測に 際しては，そこに適切な縞間隔がある。すなわち測定 者のミステイクを減少させ, かつ医学的な要求を満す 適当な值の縞間隔が存在する」という言葉である。こ のような内容を押し進めていけば標準化という問題に 到達する。そこで精度についても、コントラストにつ いても基準となるようなものが欲しい。また，撮影時 における被験者の姿勢のとらせ方にも基準が必要とな ってくる。

格子を作成する際に決定しなければならないピッチの 値と縞間隔について考察する。D. M. MEADOWS に よれば

$$
\triangle z=\frac{\bar{p}_{o} h(N+1)}{d-\bar{p}_{o}(N+1)}-\frac{\bar{p}_{o} h N}{d-\bar{p}_{o} N}
$$

なる関係がある。ここで伿は格子条のピッチで原文で 
は $p$, 本報告の記号を統一するために $\bar{P}_{o}$ と書きなおし た。

格子投影型の場合も, カメラレンズ, 光源レンズの 焦点距離を $f$, レンズと対象物体間の距離を $\bar{a}$, 両レン ズの光軸間距離を $\bar{D}$ とすれば，それらの間にはつぎの 関係があり（Fig. 3参照）

$$
\begin{aligned}
& \bar{p}=\frac{\bar{a}}{\bar{b}} \bar{p}_{o} \\
& \frac{\bar{a}}{\bar{b}}=\frac{\bar{a}-f}{f}
\end{aligned}
$$

さらに式 (3-2-12) から誘導される

$$
z_{N}=\frac{\bar{a} \bar{p} N}{\bar{D}-\bar{p} N}
$$

から

$$
z_{N}=\frac{\bar{p}_{o} \bar{a}(\bar{a}-f) N}{f \bar{D}-\bar{p}_{o}(\bar{a}-f) N}
$$

が与えられ，縞間隔は $\triangle z_{N}$ は

$$
\begin{aligned}
\triangle z_{N}=z_{N+1}-z_{N}= & \frac{\bar{a}(\bar{a}-f) f \bar{D} \bar{p}_{o}}{\left\{f \bar{D}-\overline{p_{o}}(\bar{a}-f)(N+1)\right\}} \cdot \\
& \frac{1}{\left\{f \bar{D}-\bar{p}_{o}(\bar{a}-f) N\right\}} \\
\text { or }= & \frac{(K+1) \bar{a}(\bar{a}-f) f \bar{D} \bar{p}_{s}}{\left\{f \bar{D}-(K+1) \bar{p}_{s}(\bar{a}-f)(N+1)\right\}} \cdot \\
& \frac{1}{\left\{f \bar{D}-(K+1) \bar{p}_{s}(\bar{a}-f) N\right\}}
\end{aligned}
$$

となる。

一方, 判読しやすい写真を得るということは, モア レ縞写真の場合，特に良いコントラストをもつ写真を 得るということになる。そして縞模様のコントラスト は格子の間隙率に左右される。（たとえ被写体の位置 や曲率，格子条の形状による実効間隙率による影響を 考慮したとしても）いま格子自体の間隙率として，或 る値 $K_{O}$ が最良であるといら結論が得られたとする。現 実的には我々の取得しうる糸の径に一定の規格があり， 任意の值をもつ径が簡単に手にはいるわけではない。 また格子条間の隙間を限りなく小さくとることはでき ない。すなわちモアレ写真は, 幾何光学の分野で扱 現象であって, 光の波長のからんだ限界がある。

縞間隔が標準化され，それに対応するピッチ原（い ま他の因子はレンズやレンズ間の距離によって与えら れるので, 定数のようにみなす）がある值に定められ,
一方格子間隙率の基準としてある值が示されても，格 子照射型の場合には $\bar{p}_{o}$ とと系のd'の間に $\overline{p_{o}}=(K+1)$ $d^{\prime} / K$ なる関係があり, 格子投影型の場合には $\bar{p}_{o}=$ $(K+1) \bar{p}_{S}$ なる関係があるので格子のピッチを優先す れば，間隙率（すなわちコントラスト）を犠牲にする 場合が起き，間隙率を優先すれば $\bar{P}_{0}$ を犠牲にする（縞 間隔を犠牲にする）場合が発生する。すなわち格子の 設計にあたっては，このような意味合で $K$ の值は縞間 隔に影響し， $\bar{p}_{0}$ の值はコントラストに影響する。

最後に, Fig. 9, Fig. 10 の写真から被写体の位置 や，その面の曲率が縞模様のコントラストに影響を与 えているということがうかがえる。この点に関する詳 しい考察と実験は次の報告で行う。

\section{6. あとがき}

本研究は, カナダの NRC (National Research Council) に滞在中, 行ったものである。 NRCの写真測量研究室 で過した期間の大半は, X線立体写真から解析的に脊 柱の形状を算出し，その結果を図で表現，或は CRT 上に表わす為のシステム開発に費やした。すなわち脊 柱の形状とモアレ縞写真の間に存在する相関性につい て論議している際に, モアレ写真技術に関する標淮化 の問題が出てきた。従来の経験から，格子自体のもつ 間隙率がモアレ縞写真のコントラストにどのような形 で関係しているのであろうかと考えていたので，また NRCで開発された非常に使いやすい撮影装置 (Fig. 7) や，立体写真用カメラ (Fig. 4) があったので, 今回 の実験と考察に手をつけた。従って実験の数はまだ不 充分であるが，凡その傾向と理論的な扱いの基礎はで きたと考えその一部を先ず報告する。

おわりに, 色々な面で御世話になった写真測量研究 室のHead Researcher Dr. T. J. BLACHUT, 及び研究スタ ッフの方々に厚く御礼申しあげる。

(1979.2.2 受付)

\section{参考文 献}

1. D. M. MEADOWS, W. O. JOHNSON, J. B. ALLEN. Appl. Opt. 9, 942 (1970)

2. H. TAKASHAKI. Appl. Opt. 9, 1467 (1970)

3. B. DRERUP. Eine Apparatur zur Dokumentation von Erkrankungen des Haltungs-und Bewegungsapparates durch Moiré Topografie. Juli, (1977) 